\title{
A METHODOLOGICAL FRAMEWORK FOR MAKING THE TRANSITION FROM TRADITIONAL INNOVATION TEACHING TOWARDS SERIOUS GAMES
}

\author{
Yiming $\mathrm{Ma}^{1}$, Flore Vallet ${ }^{1,2}$, François Cluzel $^{1}$, Bernard Yannou ${ }^{1}$ \\ ${ }^{1}$ Université Paris-Saclay, CentraleSupélec, Laboratoire Genie Industriel, Gif-sur-Yvette, France \\ ${ }^{2}$ IRT SystemX, Paris-Saclay, Palaiseau, France
}

\begin{abstract}
Serious games (SGs) are motivational and practical pedagogical tools that have been widely used in design education. SGs seem to be an efficient way to give instructions on innovation processes (IPs), offering unique and attractive environments to support situated learning. While there has been much interest in SGs of the IPs type, there is very little research about the design framework to reduce the complexity and time consumption of their design process. This paper presents the preliminary results of our ongoing study: a design framework adapted to innovation SGs. The framework integrates eight general design frameworks/models/methodologies for SGs. Besides, it introduces a new stage "analysis of traditional teaching experience," which conducive to the early phases of the design. We use a case study to prove the value of this stage. First, it aids designers in defining the teaching objectives of innovation SGs, that is, choosing required competencies from innovation competency frameworks. More importantly, it helps identify game mechanics that may contribute to the realization of teaching objectives. This stage should support designers successfully making the transition from traditional innovation teaching towards SGs.
\end{abstract}

Keywords: serious games, innovation processes, teaching experience, game elements, innovation games.

\section{INTRODUCTION}

Serious games (SGs) are motivational and practical pedagogical tools that have been widely used in design education in the last two decades [1,2]. Business Schools and Design Faculties have developed curriculums to teach innovation processes (IPs) as they consider innovation to be a required skill for students [3]. SGs seem to be a very efficient way to give instructions on IPs. SGs offer unique and engaging environments to support situated learning [4]. Students learn and practice the knowledge when immersing in the game scenarios that imitate the business environment in reality. Such an advantage has attracted many educators to use SGs to disseminate various innovation methodologies. Ellis et al. [5] applied the "Airplane Supply Chain Simulation" to teach Lean Six Sigma while Tan et al. [6] utilized the "TRIZzle" to instruct inventive principles of TRIZ for novices. After careful design and rigorous testing, teachers began to use these two SGs for innovation teaching.

SGs as educational products have a full lifecycle, including design, development, validation, deployment, and iterative refinement [7]. Considerable research focuses on the design processes of SGs. The design of serious games is actually to define different design elements and form them into coherent game systems. Due to varying perceptions of "design elements," there are various ways of decomposing a game system.

Studies like $[8,9]$ have provided us with general design methodologies of SGs. However, it is hard to apply them directly to design innovation SGs. We should adapt them to the specificities of teaching IPs. These specificities refer to the characteristics of the IPs courses compared to other subjects' courses in terms of learning objectives, teaching content, instructional strategies. For instance, helping students foster necessary innovation competencies is one of the pedagogy intentions of all IPs teaching [10]. This specificity should also be one of the design purposes of innovation games. Ignoring it when designing innovation SGs may lead to failure. We can imagine a situation where, after playing the game, students remember the theoretical knowledge, but they cannot apply it to solve real-world problems.

Analysis of teaching experience has two classic purposes, quality assurance and quality enhancement [11]. However, we found through a case study that it also helps us to identify the specificities of teaching IPs as well as to facilitate the design of innovation SGs. No previous study has investigated, "How can the analysis of teaching experience contribute to the design of innovation serious games?" This paper examines the question and presents the preliminary results of our ongoing study: an Innovation Serious Games Design (ISGD) framework. The 
ISGD framework integrates eight general design frameworks/models/methodologies and combines the specificities of innovation teaching. The ISGD framework that includes the stage of "analysis of traditional teaching experience" should help designers make the transition from traditional innovation teaching towards SGs.

The following sections describe related work, present the ISGD framework, introduce the case study as well as the new design stage "teaching experience analysis," illustrate the results of implementing this stage in one case study, discuss and conclude the paper.

\section{RELATED WORK}

The following subsections introduce related work in design frameworks/models/methodologies for SGs, design elements of SGs, and innovation competency frameworks.

\subsection{Design frameworks, models and methodologies for SGs}

A large and growing body of literature has investigated how to design SGs. The classification results of design frameworks/models/methodologies are also different according to distinct criteria. In this paper, we use two classification criteria.

The first classification criterion is "topic," that is, does the design framework/model/methodology serve a specific type of SGs? Based on the "topic," we can divide all of them into two categories: general and customized ones. Vermeulen et al. [12] derived a DISCO model of SGs for teachers by involving them actively in the design process. It is a general model that can guide teachers to define explicit design purposes and better plan learning activities in their SGs. Marfisi-Schottman et al. [13] proposed a 7-step general design method. This method states the roles of multiple stakeholders in serious game design, besides teachers and students. These two studies mainly focus on the conceptual design phase of SGs but say nothing about the development and the validation. Aslan [14] put forward two methodologies, "GAMED" for designing digital SGs and "IDEALLY" for measuring the quality of the game design. The former provides a detailed illustration of the complete design process for SGs; the latter lists more than 100 indicators to evaluate the software quality as well as the learning quality of SGs. In addition to the general design approaches described above, there exist some methodologies for serving specific types of SGs. Szczesna et al. [15] proposed a design methodology for SGs that aims at cognitive behavior therapy. It provides guidelines for describing game scenarios based on cognitive-behavior techniques. Cano et al. [16] put forward a methodology for the design of SGs for children with hearing impairments. It focuses on collecting and analyzing the needs of the hearing impaired and evaluating game prototypes.

The second classification criterion concerns "theoretical vs. practical." The theoretical frameworks often provide a series of heuristic suggestions for the SGs design, which require related deep expertise for users. For instance, Song \& Zhang [17] proposed a model that combined the active learning environment, flow experience, and motivation. This model consists of seven basic requirements for the active learning environment, nine dimensions of flow experience, and four essential strategy components for motivation. Only by fully considering these aspects can game designers design effective and engaging SGs. The practical frameworks involve a set of steps and diagrams to elaborate on the design process. Such frameworks are of considerable significance to novice SGs designers. The design framework of Saavedra et al. [18] describes work packages from the "requirements stage" to the "postmortem stage." Following the framework, they have developed applications for teaching elementary school math.

\subsection{Design elements of SGs}

When designing a serious game, no matter which method adopted, the ideal product is a holistic game system that offers a playful learning experience. Different game elements make up the game system. We can treat design elements as a set of building blocks or features shared by SGs.

Lameras [19] distinguished design elements into game attributes and learning attributes. Game attributes have been broadly understood as a way to summarize game rules [20]. Learning attributes are mechanics that facilitate learning in games. This classification is not detailed enough to use it to break down and further analyze SGs. Cheek et al. [21] researched into the SGs for health behavior change. Thus, they classified serious game design elements into four categories: elements contributing to enjoyable play experience, elements relating to the accessibility of online content, elements of the therapeutic relationship, and elements producing learning activities. The "therapeutic relationship" elements are not necessary for all SGs. Neither of [19] nor [21] addressed one common design element, "narrative."

Mitgutsch \& Alvarado [22] identified six essential components of a serious game: design purpose, narrative, aesthetics, mechanic, information, and framing. Their approach has been widely used to analyze the cohesiveness and coherence within the serious game system [23]. The element mechanic is crucial for helping understand how SGs impart knowledge and create a gaming experience. There are two kinds of mechanics, learning mechanics and game mechanics. The term "game mechanics" refers to methods invoked by agents for interacting with the game world [24]. "Learning mechanics" are patterns of behavior of learner interactivity [25]. Matching game mechanics and learning mechanics is a concise means to relate ludic elements and teaching objectives within the gameplay [26]. As part of the preparation work for designing innovation SGs, we conducted an in-depth study of game mechanics and established a "game mechanics space" [27]. We collected these mechanics from the literature and then found the definition and example for each of them. 


\subsection{Innovation competency frameworks}

Innovation competencies include the knowledge, skills, and attitudes required for successful innovation. Waychal et al. [28] identified seven individual innovation competencies: visioning, ability to generate ideas, internal and external networking relationships, ownership, stretch mindset, and focus on tasks. Each innovator indeed requires these competencies. Vlok [29] proposed a competency framework for innovation leaders. His framework matched twenty innovation competencies with different types of leaders (strategist, capability builder, achiever, and matchmaker). Moubdi et al. [30] offered a complete innovation competency framework. It is composed of individual competencies, collective competencies, and leadership competencies necessary to implement a need-seeker innovation. Before designing innovation SGs, designers must select the innovation competencies they want to cultivate for students from these innovation competency frameworks.

\section{INNOVATION SERIOUS GAME DESIGN FRAMEWORK}

This section introduces the motivation for proposing an Innovation Serious Game Design (ISGD) framework. ISGD framework results from four aspects: the research method to collect and select frameworks/models/methodologies for SGs, the description of the eight general design processes, the strategy to integrate the eight processes, and the definition for each stage within the ISGD framework.

\subsection{Method and scope of the study}

Szczesna et al. [15] and Cano et al. [16] have proposed design methods for specific types of SGs. They added unique attributes to general design processes according to the teaching goals. With these dedicated methods, designers reduce the design time while ensuring game quality. However, at our knowledge, there is no extensive process specific to the design of innovation SGs. Thus, we attempted to define a customized design framework that incorporates the specificities of innovation teaching. Since teachers usually do not have the expertise required to design SGs, our framework should be as practical as possible. In our study, we focused on previous design frameworks/models/methodologies that are practical and general.

To collect useful information, we used five online academic databases: IEEE Xplore, ACM Digital Library, Springer, SAGE journals, and Sciencedirect. When searching for literature, we applied the following keywords: "serious game/educational game/game-based learning" plus "design framework/model/methodology." As a result, we collected 38 papers. Among them, there were 33 papers about digital SGs and the remaining concerned entertainment games. By browsing the abstract and conclusion, we finally selected eight papers that meet our needs. Each of these studies clarified an exhaustive process consisting of different stages. Table 1 concludes their contributions.
TABLE 1: GENERAL DESIGN METHODS FOR DIGITAL SERIOUS GAMES

\begin{tabular}{|c|c|}
\hline Ref. & Contribution \\
\hline [8] & $\begin{array}{l}\text { A design methodology that facilitates the integration of } \\
\text { educational content while keeping the fun factor of SGs. }\end{array}$ \\
\hline [9] & $\begin{array}{l}\text { A framework based on participatory design theory. It clearly } \\
\text { illustrates the role of students and teachers in the various game } \\
\text { design phases. }\end{array}$ \\
\hline [13] & $\begin{array}{l}\text { A 7-step design method, showing the different participants and } \\
\text { tasks to be completed, and a set of multi-view tools that support } \\
\text { these tasks. }\end{array}$ \\
\hline [14] & $\begin{array}{l}\text { A design methodology "GAMED" for guiding the design of } \\
\text { SGs; A methodology "IDEALLY" for instructing the assessment } \\
\text { for the quality of SGs. }\end{array}$ \\
\hline$[18]$ & $\begin{array}{l}\text { A design methodology founded in the traditional software } \\
\text { engineering paradigms and complemented by co-design as well } \\
\text { as competency-based approach. }\end{array}$ \\
\hline [31] & $\begin{array}{l}\text { A design model "ATMSG" based on the activity theory: } \\
\text { supports a systematic and detailed representation of SGs; } \\
\text { depicts how game elements contribute to the desired } \\
\text { pedagogical goals. }\end{array}$ \\
\hline [32] & $\begin{array}{l}\text { A design methodology for stimulating collaborative learning } \\
\text { and enhancing communication in SGs. It also describes how to } \\
\text { plan playtests and use the results of the tests to improve SGs. }\end{array}$ \\
\hline [33] & $\begin{array}{l}\text { A methodology that promotes the design of learning role-play } \\
\text { game (LRPG) scenarios: how to collect, share, and operate } \\
\text { LRPG scenarios and components. }\end{array}$ \\
\hline
\end{tabular}

\subsection{ISGD framework}

To identify vital backbone stages for building the ISGD framework, we have performed the following process:

(1) Digital SGs are a kind of software, so they must follow the software development process. We chose the acknowledged "Waterfall model" [34] as the main structure of the ISGD framework. The waterfall model is a sequential software development approach, in which development is seen as flowing steadily downwards through several phases, typically: a) requirements gathering and analysis, b) system design, c) implementation, d) verification, and e) deployment [34].

(2) We extracted 35 design stages included in these eight frameworks/models/methodologies.

(3) We matched each design stage with the five phases in the waterfall model.

(4) We classified design stages according to the definition provided by these studies. If some stages have the same definition but use different terms, only one of them will be kept. After removing redundancy, there were a total of 19 different design stages remaining (Table 2).

(5) Sorted these design stages according to the timing relationship. 
TABLE 2: DEFINITION OF THE DESIGN STAGES FOR THE ISGD FRAMEWORK

\begin{tabular}{|c|c|}
\hline $\begin{array}{c}\text { Design stage } \\
{[8,9,13,14,18,31,32,33]}\end{array}$ & Definition \\
\hline $\begin{array}{c}\text { User/Player profile } \\
{[9,14,31,32]}\end{array}$ & $\begin{array}{l}\text { Determine the targeted audience other } \\
\text { stakeholders. }\end{array}$ \\
\hline $\begin{array}{c}\text { Instructional activities } \\
{[31,32]}\end{array}$ & $\begin{array}{l}\text { Define the relationship between SGs and } \\
\text { other teaching activities. }\end{array}$ \\
\hline $\begin{array}{c}\text { Teaching objectives } \\
{[8,9,13,14,18,31,32,33]}\end{array}$ & $\begin{array}{l}\text { Provide a detailed description of ambition } \\
\text { in terms of knowledge and competencies. } \\
\text { For IPs games, we need to determine the } \\
\text { innovation competencies to be taught. }\end{array}$ \\
\hline $\begin{array}{c}\text { Collect other design purposes } \\
{[18,32]}\end{array}$ & $\begin{array}{l}\text { Listen to stakeholders and understand their } \\
\text { expectations about game playing. }\end{array}$ \\
\hline $\begin{array}{c}\text { Teaching experiences } \\
\text { analysis }\end{array}$ & $\begin{array}{l}\text { Observe and analyze traditional innovation } \\
\text { teaching to help determine the innovation } \\
\text { competencies to be taught and identify } \\
\text { useful game mechanics. }\end{array}$ \\
\hline $\begin{array}{l}\text { Specification document of } \\
\text { the design purposes } \\
{[14]}\end{array}$ & $\begin{array}{l}\text { Write a report for summarizing of all } \\
\text { design purposes defined. }\end{array}$ \\
\hline $\begin{array}{c}\text { Quality assurance } \\
\text { (QA\#1) } \\
{[14]}\end{array}$ & $\begin{array}{l}\text { Evaluate the quality of the previous report } \\
\text { and the process for gathering design } \\
\text { purposes. }\end{array}$ \\
\hline $\begin{array}{c}\text { Define the game type } \\
{[13,14]}\end{array}$ & $\begin{array}{l}\text { Choose a game genre which determines } \\
\text { the main gameplay, such as adventure } \\
\text { game, puzzle game, or role-playing game. }\end{array}$ \\
\hline $\begin{array}{l}\text { Define game elements } \\
{[8,9,18,31,32,33]}\end{array}$ & $\begin{array}{l}\text { Generate game ideas for each element: } \\
\text { story, game mechanics, information, } \\
\text { aesthetics, and framing. Each element } \\
\text { must reflect design purposes. }\end{array}$ \\
\hline $\begin{array}{c}\text { Evaluation design } \\
{[13]}\end{array}$ & $\begin{array}{l}\text { Consider how to evaluate: player } \\
\text { performance during the gameplay; } \\
\text { learning outcomes after the gameplay. }\end{array}$ \\
\hline $\begin{array}{c}\text { Scenario specification } \\
{[13,18]} \\
\end{array}$ & $\begin{array}{l}\text { Describe each game scenario that } \\
\text { constitutes the whole game. }\end{array}$ \\
\hline $\begin{array}{c}\text { Architecture } \\
{[13,14,18,31,33]}\end{array}$ & $\begin{array}{l}\text { Describe the logical relationship between } \\
\text { different game scenarios. }\end{array}$ \\
\hline $\begin{array}{c}\text { Specification document of } \\
\text { game ideas } \\
{[8,13,14]} \\
\end{array}$ & $\begin{array}{l}\text { Write a report that summarizes all game } \\
\text { ideas. }\end{array}$ \\
\hline $\begin{array}{c}\text { Quality assurance } \\
\text { (QA\#2) } \\
{[14]}\end{array}$ & $\begin{array}{l}\text { Evaluate the quality of game ideas and the } \\
\text { process for generating game ideas. }\end{array}$ \\
\hline $\begin{array}{c}\text { Design prototypes } \\
{[13,14,18,32,33]}\end{array}$ & $\begin{array}{l}\text { Design digital or physical prototypes for } \\
\text { testing game ideas. The SGs designers } \\
\text { explain design requirements to software } \\
\text { engineers with the help of prototypes. }\end{array}$ \\
\hline $\begin{array}{c}\text { Software requirements } \\
\text { specification (SRS) } \\
{[14]}\end{array}$ & $\begin{array}{l}\text { Write a report to explain the } \\
\text { functional/non-functional requirements for } \\
\text { the software. }\end{array}$ \\
\hline $\begin{array}{c}\text { Quality assurance } \\
\text { (QA\#3) } \\
{[14]} \\
\end{array}$ & $\begin{array}{l}\text { Evaluate the quality of the previous report } \\
\text { and the requirements engineering process. }\end{array}$ \\
\hline $\begin{array}{c}\text { Game programming } \\
{[9,14,18,32,33]}\end{array}$ & $\begin{array}{l}\text { Design game software for fulfilling all } \\
\text { requirements. }\end{array}$ \\
\hline $\begin{array}{c}\text { Software test } \\
{[9,14,18,32]}\end{array}$ & $\begin{array}{l}\text { Test whether the software meets all } \\
\text { functional requirements. }\end{array}$ \\
\hline $\begin{array}{c}\text { Goal validation } \\
{[8,14,31,32,33]}\end{array}$ & $\begin{array}{l}\text { Test the game with users: confirm that all } \\
\text { design purposes have been achieved; } \\
\text { collect feedback for improving the game. }\end{array}$ \\
\hline $\begin{array}{c}\text { Deployment } \\
{[14,18]}\end{array}$ & $\begin{array}{l}\text { After rounds of iterative design, the game } \\
\text { is officially used in teaching activities. }\end{array}$ \\
\hline
\end{tabular}

After these five steps, we determined the main body of the ISGD framework. The next step is to discover the specificities of innovation teaching and introduce them into the design framework. Considering the specificities of teaching IPs, we created two stages so far. The first version of the ISGD framework (Figure 1) comprises two types of components: 1) stages come from general design methods and 2) stages determined by the specificities of teaching IPs. The rest of this paper focuses on a new stage, "teaching experience analysis." Based on the case study described in the next section, we found that "teaching experience analysis" is an effective way to support teachers to define design purposes (innovation competencies) for innovation SGs. More importantly, this stage can help determine useful game mechanics.

\section{CASE STUDY}

In this section, we introduce a case study named "Radical Innovation Design (RID) sprint," including its pedagogical intentions and schedule. We take advantage of this case to illustrate how teaching experience analysis benefits the design of innovation SGs.

\subsection{Teaching experience: RID sprint}

The RID sprint is a five-day innovation course on the subject of the RID Methodology [35], given each year in a French engineering school. It employed a traditional teaching method, "Project-based learning," students learn by actively engaging in real-world and personally meaningful projects. Two experts performed as lecturers for the course. A total of 15 master students registered for the course and formed four study groups (three groups with four students and the other one group with three students).

Two motivations supported the launching of this course: a) Deliver the core content of the RID methodology; b) Be compliant with a time-limited context. Train students to use the RID methodology to analyze the initial idea of an innovation project and gradually obtain outcomes that meet the company's expectations. To achieve these two objectives, we organized the RID sprint as following (Figure 2):

(1) For the first four days, each day of the training included two sessions. Students learned the theoretical knowledge related to the RID methodology during the first session. In the second session, students practiced the knowledge acquired before. Students must generate the expected RID deliverables related to the content of the day's teaching (Table 3). RID deliverables are templates for students to summarize research results. The more the design team completes the successive RID deliverables, the more likely the innovation outcome will be successfully launched.

TABLE 3: RID DELIVERABLES ALONG WITH THE TIMELINE

\begin{tabular}{|c|l|}
\hline Day & \multicolumn{1}{|c|}{ RID deliverables } \\
\hline 1 & $\begin{array}{l}\text { \#1 Knowledge design; \#2 Need reframing; \#3 Observation of } \\
\text { usage }\end{array}$ \\
\hline 2 & $\begin{array}{l}\text { \#4 Identification of existing solutions; \#5 Causality of problems } \\
\text { and pains }\end{array}$ \\
\hline 3 & $\begin{array}{l}\text { \#6 Usage scenarios; \#7 Value buckets identification } \\
\text { \#8 Kano analysis (optional); \#9 Ambition perimeter }\end{array}$ \\
\hline 4 & $\begin{array}{l}\text { \#10 Creativity sessions \& UNPC monitoring } \\
\text { \#11 Prototyping \& Validation } \\
\# 12 \text { Business Model Design }\end{array}$ \\
\hline
\end{tabular}




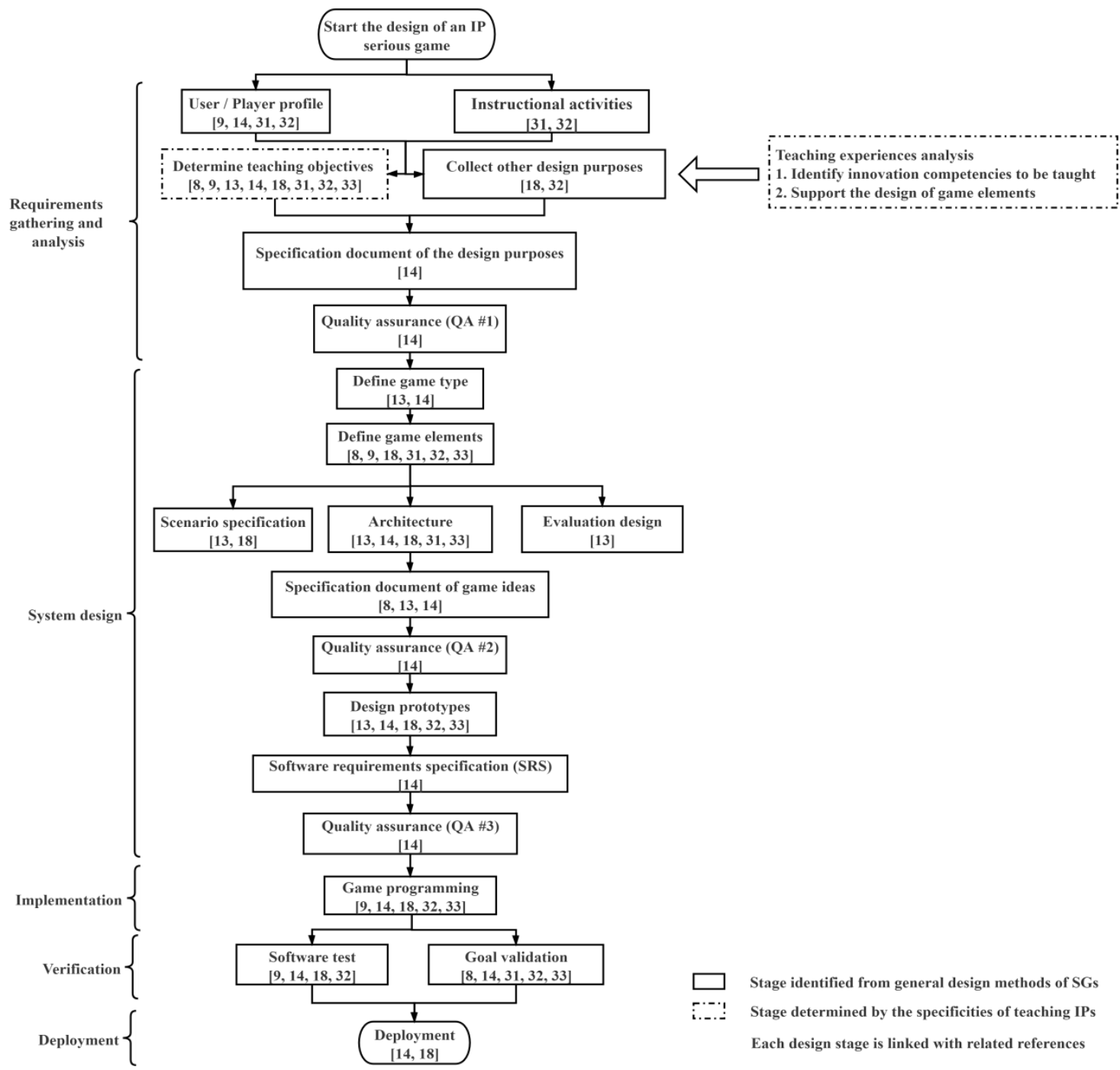

\section{FIGURE 1: INNOVATION SERIOUS GAME DESIGN (ISGD) FRAMEWORK}

(2) Students practiced the RID process in groups based on the challenge initiated by the company Groupe SEB. The challenge is "design the product of the small domestic equipment of tomorrow answering the challenges of sustainable development." Students should focus on the new needs of consumers sensitive to sustainable development challenges to propose innovative ideas of household appliances with novel features. The students encountered with an ill-structured problem, and they needed to determine a research subject first.

(3) On the second day of the course, students had a remote meeting with two company employees. Taking advantage of the meeting, students better understood the challenge and validated their ideal goals;

(4) On the fourth day, students took a half-day training of the eco-ideation to stimulate them to generate eco-innovative ideas. The eco-innovation approach was an add-on to the RID backbone of the training session. It aimed at meeting the sustainability challenge for the contest. However, in this paper, the results associated with this approach are not reported.

(5) On the last day, each group gave a presentation to illustrate how they applied RID and eco-innovation methodologies to overcome the challenge.

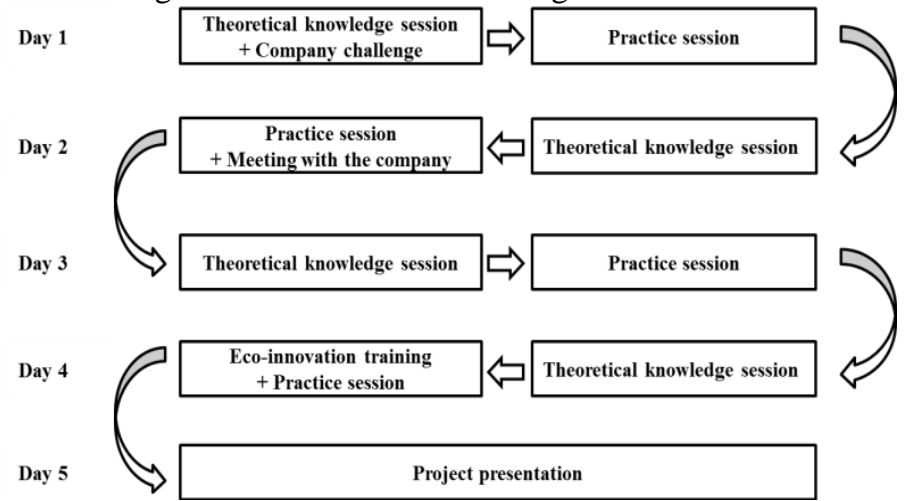

FIGURE 2: COURSE SCHEDULE 


\subsection{Teaching experience analysis}

To make the transition from the RID sprint towards a RID serious game, we implemented the stage of analyzing teaching experience (Figure 3). Before analyzing the teaching experiences of the RID sprint, the first author of this paper performed a non-participant observation to document the course flow as well as the story of each study group in dealing with the company challenge. To specify the data to collect, we designed an observation template before the course began. Every day, the observer filled out this template for each group based on the observations. The template was composed of two parts: a) details of the classroom; b) questions related to the observation focus. The first part aimed to record the date, time, and location of the observed classroom. The nature of the lesson (e.g., year level and learning focus) was also being recorded. The second part contained two questions corresponding to the observation focus:

(1) What are the learning mechanics used in the course?

(2) What are the innovation competencies involved in the practice session?

In addition to filling out the observation template and recording useful information that may appear, the observer also needed to record the progress of each innovation group through photography and video. The observation focus reflected two objectives that prompted us to analyze the teaching experiences of the RID sprint.

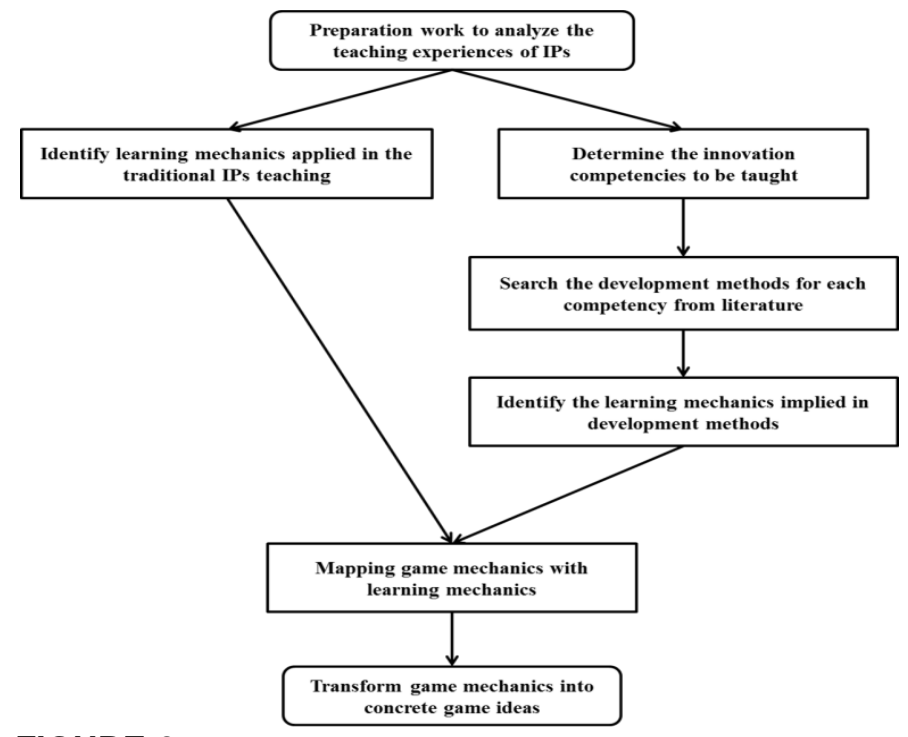

FIGURE 3: FLOWCHART OF THE TEACHING EXPERIENCES ANALYSIS STAGE BASED ON THE LM-GM FRAMEWORK [26]

The first one was relevant to learning mechanics (the left side in Figure 3). According to the Learning Mechanics-Game Mechanics (LM-GM) model [26], LM in SGs are closely related to GM. For any learning mechanic, it is doable to find at least one corresponding game mechanic. By observing the LM applied by teachers in traditional IPs teaching, we can derive GM with similar functions in SGs. The premise is to know the definitions of commonly used GM as well as LM.
The second objective is to identify the innovation competencies necessary to apply the RID methodology (the right side in Figure 3). Helping students develop these competencies will be one of the design purposes of a RID game. Yannou [35] stated, "RID is a structured methodology for exploring the front end of useful innovation in need seeker mode." Thus we chose the framework from Moubdi et al. [30] and learned in advance the definition of each competency. After determining the innovation competencies to be taught, the next step is to identify development methods for each competency from literature. These methods are essentially composed of LM, which allow deriving related GM for developing required innovation competencies. "Teaching experiences analysis" provides designers with a set of GM. In the "system design phase," each of them will be elaborated and transformed into concrete game ideas.

\section{RESULTS}

In this section, we first present the data collected through observation and then analyze how it enlightens us on the design of innovation SGs.

\subsection{Learning mechanics applied in the RID sprint}

Teachers applied many LM in this short-term training. It is because of the use of these LM that students can tirelessly learn knowledge and conquer the company challenge. We list and describe all the LM employed in the RID sprint in Table 4. These mechanics come from the LM-GM framework [26].

TABLE 4: LEARNING MECHANICS APPLIED IN THE RID SPRINT

\begin{tabular}{|c|c|}
\hline $\begin{array}{l}\text { Learning mechanics } \\
{[26]}\end{array}$ & Explanation based on [35] \\
\hline Guidance & $\begin{array}{l}\text { Teachers provide instruction about the RID } \\
\text { methodology with slides. }\end{array}$ \\
\hline Action/Task & $\begin{array}{l}\text { Students practice the RID process on a real } \\
\text { project. }\end{array}$ \\
\hline Discover & $\begin{array}{l}\text { Students search for useful information in the } \\
\text { literature and professional reports. }\end{array}$ \\
\hline Observation & Observation as an investigation strategy. \\
\hline Reflect/Discuss & $\begin{array}{l}\text { Discussion among group members; } \\
\text { Discussion between students and teachers. }\end{array}$ \\
\hline Plan & $\begin{array}{l}\text { Students develop an investigation plan to gather } \\
\text { the required knowledge. }\end{array}$ \\
\hline Motivation & $\begin{array}{l}\text { Each group has the freedom to choose a research } \\
\text { subject. }\end{array}$ \\
\hline Responsibility & Each student has a division of labor. \\
\hline Competition & Teachers evaluate the results of each group. \\
\hline Feedback & Teachers comment on students' daily outcomes. \\
\hline $\mathrm{Q} \& \mathrm{~A}$ & Teachers answer the questions from students. \\
\hline Imitation & $\begin{array}{l}\text { Students imitate the examples in slides to do their } \\
\text { projects. }\end{array}$ \\
\hline Repetition & Students iteratively improve their solutions. \\
\hline Experimentation & $\begin{array}{l}\text { Students design prototypes for testing and } \\
\text { improving solutions. }\end{array}$ \\
\hline Assessment & $\begin{array}{l}\text { Students use the UNPC (Usefulness, Newness, } \\
\text { Profitability, and Concept) tool to assess the } \\
\text { value of their solutions. }\end{array}$ \\
\hline Participation & \multirow{2}{*}{$\begin{array}{l}\text { Students participate in the final presentation and } \\
\text { introduce their results. }\end{array}$} \\
\hline Ownership & \\
\hline
\end{tabular}




\subsection{Mapping game mechanics with learning mechanics}

For the next step, we map LM with GM (Table 5). All these GM originate from the "game mechanics space" [27]. To obtain desired results, the executor must have two capabilities: understands the definition of common LM and GM; has a certain game experience, which means s/he knows rich examples of LM.

TABLE 5: MAPPING GAME MECHANICS WITH LEARNING MECHANICS

\begin{tabular}{|c|c|}
\hline Learning mechanics [26] & Game mechanics [27] \\
\hline Guidance & Cascading information \\
\hline Action/Task & Game levels, Challenges \\
\hline Discover & Communal discovery \\
\hline Observation & Cut scenes \\
\hline Reflect/Discuss & Collaboration, Voting \\
\hline Plan & $\begin{array}{c}\text { Strategy/Planning, } \\
\text { Resource management }\end{array}$ \\
\hline Motivation & $\begin{array}{l}\text { Role-playing, Tokens, } \\
\text { Behavioral momentum }\end{array}$ \\
\hline Responsibility & Competition, Social pressure \\
\hline Competition & Competition \\
\hline Feedback & Feedback, Rewards \\
\hline Q \& A & Q \& A \\
\hline Imitation & Tutorial \\
\hline Repetition & Infinite gameplay \\
\hline Experimentation & Design/Editing \\
\hline Assessment & Assessment, Progress, Budges \\
\hline Participation & Collaboration, Cooperation \\
\hline Ownership & Ownership, Tokens \\
\hline
\end{tabular}

Finally, we need to get inspiration from other games and combine our creativity to instantiate each game mechanic. Here we take the learning mechanic "guidance" as an example. "Guidance" is defined as providing students with accurate and complete procedural information and related declarative knowledge that they have not learned [36]. "Cascading information" is the theory that information should be released in the minimum possible snippets to gain the appropriate level of understanding at each point during a game narrative [37]. If designers have these two definitions in mind, it is easy to link them together. The "cascading information" is always implemented in this way: at the beginning of each game level, players are provided with the necessary guidance to accomplish all challenges of that level [38]. There are 18 sub-activities in the RID process. We assume that each RID sub-activity corresponds to a game level. Then we can realize the game mechanic "cascading information" by giving the required information (explanation of essential concepts and missions) before the students start each sub-activity.

\subsection{Determine the innovation competencies to be taught}

Through analyzing teaching experiences, we identified one specificity for teaching RID, i.e., a set of related innovation competencies. We describe the innovation competencies needed to complete each RID deliverable in Table 6.
TABLE 6: INNOVATION COMPETENCIES REQUIRED BY EACH RID DELIVERABLE

\begin{tabular}{|c|c|c|}
\hline $\begin{array}{c}\text { RID } \\
\text { deliverable }\end{array}$ & $\begin{array}{c}\text { Innovation competencies } \\
{[30]} \\
\end{array}$ & $\begin{array}{c}\text { Explanation based on } \\
{[35]} \\
\end{array}$ \\
\hline \multirow{4}{*}{$\begin{array}{c}\# 1 \\
\text { Knowledge } \\
\text { Design }\end{array}$} & $\begin{array}{c}\text { Knowledge management } \\
\text { skills }\end{array}$ & $\begin{array}{c}\text { Collect, store and share the } \\
\text { deep knowledge }\end{array}$ \\
\hline & Analytical skills & $\begin{array}{c}\text { Identify the necessary deep } \\
\text { knowledge items and } \\
\text { investigation strategies }\end{array}$ \\
\hline & Communication skills & $\begin{array}{c}\text { Discussions between group } \\
\text { members }\end{array}$ \\
\hline & Responsibility & $\begin{array}{l}\text { Students should maintain a } \\
\text { serious work attitude }\end{array}$ \\
\hline \multirow{4}{*}{$\begin{array}{c}\text { \#2 } \\
\text { Need } \\
\text { reframing }\end{array}$} & $\begin{array}{l}\text { Ability to tackle the } \\
\text { ill-structured problem }\end{array}$ & $\begin{array}{l}\text { Reformulate the vague } \\
\text { initial idea to the ideal goal }\end{array}$ \\
\hline & Analytical skills & Analyze the needs of users \\
\hline & Independent thinking skills & $\begin{array}{l}\text { Team members should } \\
\text { have the ability to perform } \\
\text { some tasks individually }\end{array}$ \\
\hline & Collective intelligence & $\begin{array}{c}\text { Collaboration between } \\
\text { group members }\end{array}$ \\
\hline \multirow{5}{*}{$\begin{array}{c}\text { \# } 3 \\
\text { Observation } \\
\text { of usage }\end{array}$} & $\begin{array}{l}\text { Knowledge management } \\
\text { skills }\end{array}$ & $\begin{array}{c}\text { Collect the deep } \\
\text { knowledge about existing } \\
\text { usage situations }\end{array}$ \\
\hline & Analytical skills & $\begin{array}{c}\text { Analyze the problems and } \\
\text { usage situations }\end{array}$ \\
\hline & Synthesizing skills & $\begin{array}{c}\text { Do the categorization of } \\
\text { usage situations }\end{array}$ \\
\hline & Empathy skills & Identify the problems \\
\hline & Curiosity & $\begin{array}{l}\text { Motivate team members } \\
\text { for in-depth research }\end{array}$ \\
\hline \multirow{2}{*}{$\begin{array}{l}\text { \# } 4 \\
\text { Identification } \\
\text { of existing } \\
\text { solutions }\end{array}$} & $\begin{array}{l}\text { Knowledge management } \\
\text { skills }\end{array}$ & $\begin{array}{c}\text { Collect the deep } \\
\text { knowledge about the } \\
\text { existing solutions }\end{array}$ \\
\hline & $\begin{array}{l}\text { Problem-solution pairing, } \\
\text { Analytical skills }\end{array}$ & $\begin{array}{l}\text { Matching problems with } \\
\text { existing solutions }\end{array}$ \\
\hline \multirow{2}{*}{$\begin{array}{c}\text { \# } 5 \\
\text { Causality of } \\
\text { problems and } \\
\text { pains }\end{array}$} & $\begin{array}{c}\text { Knowledge management } \\
\text { skills }\end{array}$ & Apply the deep knowledge \\
\hline & Analytical skills & $\begin{array}{l}\text { Analyze the causes and the } \\
\text { consequences of problems }\end{array}$ \\
\hline $\begin{array}{c}\# 6 \\
\text { Usage } \\
\text { scenarios }\end{array}$ & Analytical skills & $\begin{array}{l}\text { Analyze the coverage and } \\
\text { the efficiency of existing } \\
\text { solutions on the usage } \\
\text { situations }\end{array}$ \\
\hline $\begin{array}{l}\quad \# 7 \\
\text { Value buckets } \\
\text { identification }\end{array}$ & $\begin{array}{l}\text { Synthesizing skills, } \\
\text { Analytical skills, } \\
\text { Collective intelligence }\end{array}$ & $\begin{array}{l}\text { Synthesize different } \\
\text { aspects of deep knowledge } \\
\text { and then fill out the three } \\
\text { matrices of the DSM value } \\
\text { bucket tool by discussions }\end{array}$ \\
\hline \multirow{4}{*}{$\begin{array}{l}\text { \# } 9 \\
\text { Ambition } \\
\text { perimeter }\end{array}$} & Communication skills & $\begin{array}{l}\text { Discussions between the } \\
\text { company and students }\end{array}$ \\
\hline & Analytical skills & $\begin{array}{l}\text { Analyze and select value } \\
\text { buckets }\end{array}$ \\
\hline & Creativity & $\begin{array}{c}\text { Imagine dreamed usage } \\
\text { scenarios and solutions }\end{array}$ \\
\hline & Analytical skills & $\begin{array}{c}\text { Analyze the usefulness, } \\
\text { newness, profitability and } \\
\text { concept advantages of each } \\
\text { solution }\end{array}$ \\
\hline
\end{tabular}


TABLE 6: INNOVATION COMPETENCIES REQUIRED BY EACH RID DELIVERABLE, CONTINUED

\begin{tabular}{|c|c|c|}
\hline $\begin{array}{c}\text { RID } \\
\text { deliverable }\end{array}$ & $\begin{array}{l}\text { Innovation competencies } \\
{[30]}\end{array}$ & $\begin{array}{c}\text { Explanation based on } \\
{[35]}\end{array}$ \\
\hline \multirow{3}{*}{$\begin{array}{l}\text { \# } 9 \\
\text { Ambition } \\
\text { perimeter }\end{array}$} & $\begin{array}{l}\text { Collective intelligence, } \\
\text { Independent thinking }\end{array}$ & $\begin{array}{l}\text { To obtain satisfactory } \\
\text { results, each team member } \\
\text { needs to contribute }\end{array}$ \\
\hline & Problem-solution pairing & $\begin{array}{l}\text { Positioning and choice of a } \\
\text { final concept }\end{array}$ \\
\hline & Idea association skills & $\begin{array}{c}\text { Reasonably merge similar } \\
\text { solutions }\end{array}$ \\
\hline $\begin{array}{c}\text { \#11 } \\
\text { Prototyping } \\
\text { \& Validation }\end{array}$ & $\begin{array}{c}\text { Creativity, } \\
\text { Experimenting and } \\
\text { prototyping skills }\end{array}$ & Design prototypes \\
\hline $\begin{array}{c}\# 12 \\
\text { Business } \\
\text { Model } \\
\text { Design } \\
\end{array}$ & Analytical skills & $\begin{array}{c}\text { Analyze the value chain of } \\
\text { a solution and its various } \\
\text { business functions }\end{array}$ \\
\hline Remark & \multicolumn{2}{|c|}{$\begin{array}{l}\text { The RID deliverable \# } 8 \text { Kano analysis was not considered } \\
\text { due to time }\end{array}$} \\
\hline
\end{tabular}

After determining the competencies to be taught in innovation SGs, we need to process each of them further, as shown in Figure 3. By doing so, we establish a bridge between innovation competencies and GM. For example, "knowledge management (KM) skills" are essential competencies for students to complete the company challenge. Through repeating the knowledge management process, students can improve their KM skills [39]. One of the design purposes of a RID serious game is to provide the opportunity for students to practice the RID process. The RID process covers all stages of knowledge management, from the information collection, information storage, to the use of the information. We design game challenges to help players understand every RID sub-activities. Therefore, they will practice KM skills when playing the game. Here, we need to consider how to develop a suitable environment for players to improve their KM skills [40].

\section{DISCUSSION}

The ISGD framework is a practical design framework that consists of various detailed stages. Compared with $[8,9,13,14$, $18,31,32,33]$, the ISGD framework is more comprehensive as it integrates all the design steps involved in these general design frameworks/models/methodologies. Although these studies all believe that GM are crucial elements of SGs design, none of them have suggested an actual approach for identifying effective GM. The stage "teaching experiences analysis" fills this gap. We have employed it to identify GM that are useful for designing the RID game. We recommend using this approach to design different types of SGs to test its effectiveness further. This stage is based on the LM-GM framework [26]. The LM-GM framework is useful for identifying and highlighting the primary teaching and ludic features of SGs. It is more suitable for SGs analysis. Our framework is dedicated to SGs design.

The ISGD framework adopts the waterfall model, which consistent with a typical engineering design loop [41]. This nature facilitates teachers (novice designers) in the field of design engineering to understand the design process for IPs games. Improving teachers' expertise in SGs design may help optimize production time. The significance of innovation SGs for design engineering education lies in two aspects. First, they provide students with opportunities to apply the knowledge practically. Second, they offer a way for teachers to assess students' learning outcomes.

The ISGD framework is adapted to IPs games since it incorporates the specificities of innovation teaching. We can generalize it to other types of SGs by introducing the specificities for teaching other subjects. For example, when designing therapeutic games, the first stage is also to define design purposes. However, we are no longer concerned about "innovative competencies" but "therapeutic objectives (e.g., short and long-term effects)."

The most important limitation lies in the fact that the stage "teaching experience analysis" was put forward based on one case. Whether it is suitable for designing other innovation games remains to be verified. The second limitation is that the new stage has specific requirements for executors. They should be familiar with game mechanics and learning mechanics, and also have rich gaming experiences. Novice designers may not meet these requirements.

Further studies regarding the supporting tools for facilitating this stage would be worthwhile. In future investigations, we also need to identify other specificities for teaching IPs and add them to the ISGD framework. Senior educators in the design community may be able to give us useful insights. Finally, we will validate the whole framework by evaluating the quality of its application, a RID serious game. We will organize game sessions and invite potential users (students and professionals) to test the game. Combining and integrating formative and summative assessment, we will focus on evaluating three aspects:

(1) Knowledge retention of essential RID concepts (short-term and long-term);

(2) Mastery of required innovation competencies;

(3) Gameplay experience [42].

\section{CONCLUSION}

A search of the literature revealed few studies which focus on the dedicated design method of innovation SGs. Without the method, the design of innovation games still a complex issue. In this paper, we present an integrated ISGD framework. Taking into accounts the specificities of teaching IPs, we created two new stages. The "teaching experience analysis" stage is our core contribution.

We answer the research question through a case study: "How can the analysis of teaching experience contribute to the design of innovation serious games?" There are two advantages to analyzing traditional teaching experience. On the one hand, it helps teachers determine the design purposes of an innovation game, the set of competencies required by a specific innovation process. On the other hand, this stage is conducive to deriving 
useful GM from the LM adopted in traditional courses as well as the LM implied in general development methods for innovation competencies. Hopefully, this on-going research will provide some insights into innovation SGs design to solve the difficulties encountered by novice game designers.

\section{ACKNOWLEDGMENTS}

We wish to acknowledge all the students that took part in the RID sprint course. Also, we gratefully acknowledge the financial support from the China Scholarship Council (CSC). This research work has been carried out in the framework of the Technological Research Institute SystemX, and therefore granted with public funds within the scope of the French Program "Investissements d'Avenir."

\section{REFERENCES}

[1] Bulmer, L. (2009). The use of lego® serious play in the engineering design classroom. Proceedings of the Canadian Engineering Education Association (CEEA).

[2] Kerga, E., Akaberi, A., Tasich, M., Rossi, M., \& Terzi, S. (2012, September). Lean product development: Serious game and evaluation of the learning outcomes. In IFIP International Conference on Advances in Production Management Systems (pp. 590-597). Springer, Berlin, Heidelberg.

[3] Wrigley, C., \& Straker, K. (2017). Design thinking pedagogy: The educational design ladder. Innovations in Education and Teaching International, 54(4), 374-385.

[4] Taisch, M., \& Fradinho, M. (2013, September). Using Serious Game in Sustainable Global Manufacturing Education. In IFIP International Conference on Advances in Production Management Systems (pp. 99-107). Springer, Berlin, Heidelberg.

[5] Ellis, S. C., Goldsby, T. J., Bailey, A. M., \& Oh, J. Y. (2014). Teaching lean six sigma within a supply chain context: The airplane supply chain simulation. Decision Sciences Journal of Innovative Education, 12(4), 287-319.

[6] Tan W., Noor, N. F. M., \& Wang, Y. (2014). Gamification of Inventive Principles: A Case Study of Triz Puzzle Game. In Proceedings of the Serious Games Conference 2014 (Vol. 19, pp. 159-164).

[7] Alonso-Fernandez, C., Rotaru, D. C., Freire, M., Martinez-Ortiz, I., \& Fernandez-Manjon, B. (2017, November). Full Lifecycle Architecture for Serious Games: Integrating Game Learning Analytics and a Game Authoring Tool. In Joint International Conference on Serious Games (pp. 73-84). Springer, Cham.

[8] Barbosa, A. F., Pereira, P. N., Dias, J. A., \& Silva, F. G. (2014). A new methodology of design and development of serious games. International Journal of Computer Games Technology, 2014.

[9] Ismail, R., \& Ibrahim, R. (2017, July). PDEduGame: Towards participatory design process for educational game design in primary school. In 2017 International Conference on Research and Innovation in Information Systems (ICRIIS) (pp. 1-6). IEEE.
[10] Loewe, P., \& Dominiquini, J. (2006). Overcoming the barriers to effective innovation. Strategy \& leadership.

[11] Biggs, J. (2003). Teaching for quality learning at university: What the student does. Buckingham, UK: SRHE and Open University Press.

[12] Vermeulen, M., Mandran, N., \& Labat, J. M. (2016, April). DISCO, a Formal Model of Serious Games to Help Teachers at the Design Stage.

[13] Marfisi-Schottman, I., George, S., \& Tarpin-Bernard, F. (2010, October). Tools and methods for efficiently designing serious games. In Proceedings of the 4th Europeen Conference on Games Based Learning ECGBL (pp. 226-234).

[14] Aslan, S. (2016). Digital Educational Games: Methodologies for Development and Software Quality (Doctoral dissertation, Virginia Tech).

[15] Szczesna, A., Tomaszek, M., \& Wieteska, A. (2012). The methodology of designing serious games for children and adolescents focused on psychological goals. In Information Technologies in Biomedicine (pp. 245-255). Springer, Berlin, Heidelberg.

[16] Cano, S., Arteaga, J. M., Collazos, C. A., Gonzalez, C. S., \& Zapata, S. (2016). Toward a methodology for serious games design for children with auditory impairments. IEEE Latin America Transactions, 14(5), 2511-2521.

[17] Song, M., \& Zhang, S. (2008, June). EFM: A model for educational game design. In International Conference on Technologies for e-Learning and Digital Entertainment (pp. 509-517). Springer, Berlin, Heidelberg.

[18] Saavedra, A. B., Rodríguez, F. J. Á., Arteaga, J. M., Salgado, R. S., \& Ordoñez, C. A. C. (2014, September). A serious game development process using competency approach: Case Study: Elementary School Math. In Proceedings of the XV International Conference on Human Computer Interaction (pp. 1-9).

[19] Lameras, P. (2015). Essential features of serious games design in higher education. Learning, 4(5).

[20] Lundgren, S., \& Bjork, S. (2003, November). Game mechanics: Describing computer-augmented games in terms of interaction. In Proceedings of TIDSE (Vol. 3).

[21] Cheek, C., Fleming, T., Lucassen, M. F., Bridgman, H., Stasiak, K., Shepherd, M., \& Orpin, P. (2015). Integrating health behavior theory and design elements in serious games. JMIR mental health, 2(2), e11.

[22] Mitgutsch, K., \& Alvarado, N. (2012, May). Purposeful by design? A serious game design assessment framework. In Proceedings of the International Conference on the foundations of digital games (pp. 121-128).

[23] Le Compte, A., Elizondo, D., \& Watson, T. (2015, May). A renewed approach to serious games for cyber security. In 2015 7th International Conference on Cyber Conflict: Architectures in Cyberspace (pp. 203-216). IEEE.

[24] Sicart, M. (2008). Defining game mechanics. Game Studies, 8(2), n.

[25] Plass, J. L., Homer, B. D., Kinzer, C., Frye, J., \& Perlin, K. (2011). Learning mechanics and assessment mechanics for games for learning. G4LI White Paper, 1, 2011. 
[26] Arnab, S., Lim, T., Carvalho, M. B., Bellotti, F., De Freitas, S., Louchart, S., ... \& De Gloria, A. (2015). Mapping learning and game mechanics for serious games analysis. British Journal of Educational Technology, 46(2), 391-411.

[27] Ma, Y., Vallet, F., Cluzel, F., \& Yannou, B. (2019, July). Analysing The Relevance Of Serious Game Elements For Effectively Teaching Innovation Processes. In Proceedings of the Design Society: International Conference on Engineering Design (Vol. 1, No. 1, pp. 439-448). Cambridge University Press.

[28] Waychal, P., Mohanty, R. P., \& Verma, A. (2011). Determinants of innovation as a competence: an empirical study. International Journal of Business Innovation and Research, 5(2), 192-211.

[29] Vlok, A. (2012). A leadership competency profile for innovation leaders in a science-based research and innovation organization in South Africa. Procedia-Social and Behavioral Sciences, 41, 209-226.

[30] Moubdi, D., Yannou, B., Cluzel, F., Ghaffari, A., Vè ne-Rautureau, C., \& Jammes, P. (2018, September). Competency framework to support need seeker innovation training.

[31] Carvalho, M. B., Bellotti, F., Berta, R., De Gloria, A., Sedano, C. I., Hauge, J. B., \& Rauterberg, M. (2015). An activity theory-based model for serious games analysis and conceptual design. Computers \& education, 87, 166-181.

[32] Corrigan, S., Zon, G. D. R., Maij, A., McDonald, N., \& Mårtensson, L. (2015). An approach to collaborative learning and the serious game development. Cognition, Technology \& Work, 17(2), 269-278.

[33] Mariais, C., Michau, F., \& Pernin, J. P. (2012). A description grid to support the design of learning role-play games. Simulation \& Gaming, 43(1), 23-33.

[34] Bell, T. E., \& Thayer, T. A. (1976, October). Software requirements: Are they really a problem?. In Proceedings of the 2nd international conference on Software engineering (pp. 61-68). IEEE Computer Society Press.

[35] Yannou, B. (2015). Supporting need seeker innovation: the Radical Innovation Design methodology. In DS 80-8 Proceedings of the 20th International Conference on Engineering Design (ICED 15) Vol 8: Innovation and Creativity, Milan, Italy, 27-30.07. 15 (pp. 051-060).

[36] Clark, R. E. (2009). How much and what type of guidance is optimal for learning from instruction. Constructivist instruction: Success or failure, 158-183

[37] Narayanan, A. (2014). Gamification for Employee Engagement. Packt Publishing Ltd.

[38] Wang, Y., Rajan, P., Sankar, C. S., \& Raju, P. K. (2016). Let them play: the impact of mechanics and dynamics of a serious game on student perceptions of learning engagement. IEEE Transactions on Learning Technologies, 10(4), 514-525.

[39] Benckendorff, P. (2009). Using wikis to help first year students develop collaborative knowledge management skills for tomorrow.
[40] Servin, G., \& De Brun, C. (2005). ABC of knowledge management. NHS National Library for Health: Specialist Library, 20.

[41] Plan, E. T., \& Khandani, S. (2005). Engineering design process.

[42] Ibrahim, A., Vela, F. L. G., Rodríguez, P. P., Sánchez, J. L. G., \& Zea, N. P. (2012). Educational video game design based on educational playability: A comprehensive and integrated literature review. International Journal on Advances in intelligent Systems, 5(3). 